\title{
Margaret McCartney: Are we reviewing GP referrals for the right reasons?
}

\author{
Margaret McCartney general practitioner
}

Glasgow

NHS England wants all GP referrals to secondary care to be peer reviewed, and it believes that this can reduce referrals by "up to 30\%." The plans have met with shock and outrage in the tabloid press.

Outrage is justified, but for rather different reasons. This is yet another example of non-evidence based policy making, capable of doing more harm than good. And it's not a new idea. The NHS has been looking at similar proposals for years.

The $B M J$ reported in January that a third of clinical commissioning groups have employed private companies to scrutinise referrals: three quarters were unable to show whether they'd saved any money. ${ }^{2}$ Some private companies rejected referrals if they didn't fit within guidelines, and GPs were told that they'd have to challenge rejections and then have their challenges adjudicated by an "independent specialist." "Some private companies are keen to emphasise how marvellously they have reduced referrals, but there's little or no reckoning of harms from delayed diagnosis or inconvenience for patients.

Then there's the opportunity cost. When GPs are sorting out bureaucratic tangles they're not available to do more worthwhile work. Any talk of "no decision about me, without me" from back in 2012 seems dead in the water. ${ }^{4}$ Or, as a 2014 review put it, "more research is needed to develop and evaluate interventions that acknowledge the role of the patient in the referral decision." 5

No good evidence has shown that this will work. Referral management doesn't reduce outpatient attendance rates. ${ }^{6} \mathrm{We}$ have no details of the peer review that NHS England seems to desire. Some publications do suggest that variability between practices can be reduced by using peer review for referrals for lower urinary tract symptoms ${ }^{7}$ - but, crucially, this was part of a supportive package that also provided education, not blame.

GPs are often nicknamed "gatekeepers," but in austerity-onomics we've been recast as barrier builders

Indeed, we should question the purpose of peer review. If it's to improve care we should work out the best way to do it; notably, this should include asking whether referrals are made often enough and soon enough. If the sole purpose is reducing referrals we should ask what the harm is and how we'll recognise it. GPs are often nicknamed "gatekeepers," but in austerity-onomics we've been recast as barrier builders.

I'm old enough to remember that we used to phone consultants for advice, talk to our colleagues when we questioned our own judgment, and have joint meetings between primary and secondary care doctors to discuss how best to run referrals locally. I even remember when consultants used to read the referrals they were sent, upgrade some to urgent, downgrade some to routine, and phone to discuss queries and how to proceed (in some places-whisper it-this still happens). The new GP cluster working in Scotland offers opportunities to get back to these kinds of essential basics. I'd love for consultants and GPs to talk to each other, without a referral manager in the middle.

bmj.com News: GP referrals under fire (BMJ 2017;358:j4228, doi:10. 1136/bmj.j4228)

Competing interests: See www.bmj.com/about-bmj/freelancecontributors/margaret-mccartney.

Provenance and peer review: Commissioned; not externally peer reviewed.

Follow Margaret on Twitter, @mgtmccartney

Jacobs M. GPs to be asked to "peer review" referrals[article]. Pulse 2017;358. www. pulsetoday.co.uk/news/clinical-news/gps-to-be-asked-to-peer-review-all-referrals/20035161. article.

2 lacobucci G. Referral management schemes: good for whom?BMJ 2017;358:i6856. doi: 10.1136/bmj.i6856 pmid:28052861.

3 Matthews-King A. Private referral management service charges 10 per GP referral[article] Pulse 2016;358. www.pulsetoday.co.uk/news/commissioning/commissioning-topics/ referrals/private-referral-management-service-charges-10-per-gp-referral/20033096.article.

4 Department of Health. Liberating the NHS-no decision about me, without me: governmen response. 13 Dec 2012. https://www.gov.uk/government/uploads/system/uploads/ attachment data/file/216980/Liberating-the-NHS-No-decision-about-me-without-meGovernment-response.pdf.

5 Blank L, Baxter S, Woods HB, et al. Referral interventions from primary to specialist care: a systematic review of international evidence. Br J Gen Pract 2014;358:e765-74. doi:10. 3399/bjgp14X682837 pmid:25452541.

6 Cox JMS, Steel N, Clark AB, Kumaravel B, Bachmann MO. Do referral-management schemes reduce hospital outpatient attendances? Time-series evaluation of primary care 
referral management. Br J Gen Pract2013;358:e386-92. doi:10.3399/bjgp13X668177 pmid: 23735409.

South Norfolk Healthcare Community Interest Company. Quality and productivity case study. 18 July 2016. https://www.nice.org.uk/

savingsandproductivityandlocalpracticeresource? $\mathrm{id}=2593$.
Published by the BMJ Publishing Group Limited. For permission to use (where not already granted under a licence) please go to http://group.bmj.com/group/rights-licensing/ permissions 